\title{
BIOREMEDIASI Pb OLEH BAKTERI INDIGEN LIMBAH CAIR AGAR
}

Senja Ikerismawati ${ }^{*}$

${ }^{1}$ Universitas Yudharta Pasuruan, Jl. Yudharta No 7 (Pesantren Ngalah) Sengon Agung Purwosari Pasuruan Jawa Timur 67152

*Corresponding author, e-mail: *rismawati@yudharta.ac.id

\section{ABSTRACT}

Bacteria isolated from ad environment contaminated with heavy metals are very potential as heavy metal bioremediation agents called indigenous bacteria. The purpose of this study was to isolate and identify indigenic bacteria that have the potential as $\mathrm{Pb}$ bioremediation agents in agar liquid waste and to analyze the ability of indigenic bacteria in reducing $\mathrm{Pb}$. The research design used Completely Randomized Design (RAL) two factorial with variation of bacteria and eight days of treatment. Data were analyzed using two-way ANOVA with Duncan's advanced test. The results showed that there were eight isolates resulting from the isolation of agar liquid waste. The isolates of liquid waste indigen bacteria so that the most potential in reducing $\mathrm{Pb}$ were isolated $\mathrm{H}, \mathrm{E}$ and $\mathrm{F}$. The three isolates were able to reduce $\mathrm{Pb}$ in sterile agar liquid waste by $82.6 \%, 81.3 \%$ and $79.3 \%$ for eight days of treatment. The identification results using Microbact TM GNB 12A / B / E, 24 Identification Kits showed that $\mathrm{H}$ bacterial isolates were Bacillus alvei, E isolates were Bacillus pumilus species and $\mathrm{F}$ isolates were Bacillus lichenformis species

Keywords: Bioremediation, Indigenous, Bacteria, Pb, Agar Liquid Waste

\section{PENDAHULUAN}

Perkembangan dan kemajuan teknologi yang berhubungan dengan pembangunan di sektor industri banyak memberikan keuntungan, akan tetapi kemajuan teknologi juga memberikan dampak buruk. Pembangunan di bidang industri tidak jarang menimbulkan dampak negatif berupa limbah yang dihasilkan baik dalam bentuk padat, cair dan gas (Khasanah, 2009). Meningkatnya industrialisasi akan menyebabkan pula meningkatnya keluaran bahan kimia berbahaya ke lingkungan yang berasal dari limbah industri, terutama limbah yang mengandung logam berat (Gerdhart, dkk, 2008). Kontaminasi oleh logam berat menjadi perhatian serius karena dapat mencemari lingkungan, terakumulasi dalam tumbuhan dan hewan sehingga dapat masuk ke dalam rantai makanan yang dapat menyebabkan penyakit-penyakit degeratif (Zahoor \& Rehman, 2009). Salah satu logam berat yang memiliki tokisitas tinggi adalah $\mathrm{Pb}$. Logam $\mathrm{Pb}$ merupakan neuro toxin yang bersifat kumulatif, destruktif dan kontinu pada sistem haemofilik, kardiovaskuler dan ginjal (Gusnita, 2012)

Logam berat bersifat nonbiodegradable sehingga proses degradasi dan reduksi logam berat tidak semudah mendegradasi limbah organik (Gupta \& Rastolgi, 2008). Degradasi dan reduksi logam berat dapat dilakukan dengan cara fisik dan kimia melalui pertukaran ion, presipitasi, koagulasi, inverse osmosis dan adsorpsi. Semua metode tersbut cukup efisien tetapi akan sangat merugikan jika digunakan untuk mengelola limbah industri, karena relatif mahal, membutuhkan energi dan bahan kimia yang cukup besar (Zulaiaka, dkk., 2012) serta membutuhkan peralatan khusus (Park, dkk., 2010). Pendekatan secara bioteknologi dengan menggunakan bakteri 
merupakan alternatif cara yang dapat dilakukan untuk masa yang akan datang dan merupakan rekayasa yang cukup menjanjikan (Vijayaraghavan \& Yun, 2008). Pendekatan secara bioteknologi secara teknis maupun ekonomis sangat menguntungkan dan merupakan cara yang ramah lingkungan (Suhendrayatna, 2011). Bioteknologi menggunakan bakteri disebut bioremediasi, merupakan proses penghilangan logam dengan memanfaatkan aktivitas metabolisme mikroogranisme (Lutfi, dkk., 2018). Bakteri indigen merupakan bakteri yang diisolasi dari limbah itu sendiri yang secara alamiah hidup pada limbah, sehingga berpotensi dalam proses bioremediasi (Fidiastuti \& Suarsini, 2017)

Hasil Observasi limbah cair industri penepungan agar di PT Agar X, Lawang Malang diperoleh data bahwa limbah cair proses penepungan agar mengandung logam berat $\mathrm{Pb}$ sebesar $2,42 \mathrm{mg} / \mathrm{L}$. Nilai tersebut sangat tinggi apabila dibandingkan dengan persyaratan logam berat $\mathrm{Pb}$ dalam air berdasarkan Peraturan Pemerintah RI No 82 Tahun 2001, nilai ambang batas logam berat $\mathrm{Pb}$ untuk baku mutu air kelas 1 sampai dengan kelas 3 adalah sebesar 0,003 mg/L. Mengacu kepada fakta tersebut bahwa kandungan logam $\mathrm{Pb}$ dalam limbah cair industri pengolahan tepung agar telah melebihi ambang batas baku mutu air.

\section{MET ODE}

Penelitian ini merupakan penelitian deskriktif eksploratif dengan pendekatan observasi laboratorium yang bertujuan untuk mengisolasi dan mengidentifikasi bakteri indigen yang berpotensi sebagai agensia bioremidasi $\mathrm{Pb}$ pada limbah cair penepungan agar. Alat yang digunakan adalah autoclaf, cawan Petri, tabung reaksi, erlenmeyer, batang pengaduk, erlenmeyer, gelas ukur, timbangan analitik, lemari pendingin, kompor gas, kontainer es, plastik steril, botol steril, inkubator shaker, aminar air flow, inkubator, tabung reaksi, votex, mikro pipet $5 \mathrm{ml}$ dan $10 \mathrm{ml}$, rak tabung, bunsen, jarum ose, colony ounter, mikroskop, kaa benda, kaca benda cekung, kaca penutup, mangkuk pewarna kawat penyangga, pipet, pinset, bunsen, botol penyemprot dan jarum ose. Bahan yang digunakan adalah medium Luria Bertani, nutrien agar, nutrien cair, pepton, sampel limbah cair, alkohol 70\%, aquades steril, lisol, kertas penghisap, sabun cuci, bahan pewarnaan gram, alumunium foil, kertas label, tissu, kapas dan kasa

\section{Cara Kerja}

Cara kerja penelitian ini sesuai dengan Pambudiono dkk (2017) dengan modifikasi.

Pengambilan Sampel Air Limbah

Sampel air limbah diambil dari kolam IPAL PT Agar X di Lawang, Malang menggunakan botol sampel steril pada tiga titik pengambilan dengan tiga kali ulangan dan ditransportasikan dalam termos berisi es menuju laboratorium dan disimpan di lemari es selama penelitian berlangsung.

\section{Isolasi Bakteri Resisten Pb}

Sampel limbah sebanyak $50 \mathrm{ml}$ dicampurkan dengan medium Luria Bertani $450 \mathrm{ml}$ yang telah ditambah dengan $\mathrm{Pb}\left(\mathrm{NO}_{3}\right)_{2}$ sebanyak 1,65 mg sehingga konsentrasi logam berat $\mathrm{Pb}$ dalam $500 \mathrm{ml}$ (limbah cair + medium Luria bertani) sebesar 3,3 ppm dan dikocok menggunakan shaker dengan kecepatn 100 rpm selama 7 hari. Setelah 7 hari, sampel limbah diambil sebanyak $1 \mathrm{ml}$ diencerkan hingga konsentrasi $10^{-10}$ menggunakan pepton water $9 \mathrm{ml}$ dan diinokulasikan kedalam medium lempeng NA$\mathrm{Pb}$ dan diinkubasi selama $2 \times 24$ jam pada suhu $37^{\circ} \mathrm{C}$. Koloni bakteri yang tumbuh pada medium lempeng dipurifikasi hingga diperoleh isolat murni dan dilakukan pengkodean dan pengamatan morfologi. 


\section{Uji Reduksi Pb Oleh Isolat Bakteri}

Uji kemampuan isolat bakteri dalam menurunkan (mereduksi) Pb dilakukan dengan menginokulasikan tiap isolat bakteri hasil isolasi pada limbah cair agar steril selama 8 hari. Biakan murni tiap isolat bakteri dibiakkan dalam medium NC dengan konsentrasi $1,5 \times 10^{8}$ diinokulasikan kedalam botol sampel berisi limbah cair agar steril dengan rasio 1:10 dan digunakan kontrol adalah aquades steril. Dikocok menggunakan shaker dengan kecepatan 100rpm. Setiap hari selama 8 hari dilakukan analisis konsentrasi $\mathrm{Pb}$ menggunakan metode spektrofotometry. Data dinalisis menggunakan ANAVA dua arah dengan uju lanjut Duncan dengan menggunakan software SPSS ver 18.

Karakterisasindan Identifikasi Isolat Bakteri

Bakteri paling potensial dalam mereduksi $\mathrm{Pb}$ yang terpilih selanjutnya dilakukan karakterisasi dan indentifikasi menggunakan Microbact TM GNB 12A/B/E, 24 Identification Kits. Data hasil isolasi bakteri indigen limbah cair agar dianalisis secara deskriptif.

\section{HASIL DAN PEMBAHASAN}

Isolasi bakteri indigen Limbah cair agar (LCA) berhasil memperoleh 8 isolat bakteri yang dapat hidup dan tumbuh dalam medium Luria Bertani yang diperkaya dengan $\mathrm{Pb}\left(\mathrm{NO}_{3}\right)_{2}$ dengan konsentrasi sebesar 3,3 ppm. Adapun ciri morfologi kedelapan isolat bakteri hasil isolasi disajikan pada Tabel 1.

Tabel 1. Ciri Morfologi Isolat Bakteri Indigen Hasil Isolasi

\begin{tabular}{clllll}
\hline Kode Koloni & Warna & Bentuk & Tepi & Elevasi & $\begin{array}{l}\text { Mengkilat/su } \\
\text { ram }\end{array}$ \\
\hline A & krem & bundar & Kerang & datar & suram \\
B & krem & bundar & Licin & timbul & mengkilat \\
C & putih & bundar & menyebar & datar & suram \\
D & krem & konsentris & Berlekuk & datar & suram \\
E & putih & tak beraturan & Berlekuk & datar & suram \\
F & krem & bundar & Kerang & timbul & suram \\
G & putih & bundar & menyebar & datar & suram \\
H & putih & tak beraturan & $\begin{array}{l}\text { Tak } \\
\text { beraturan }\end{array}$ & datar & suram \\
\hline
\end{tabular}

Kedelapan macam isolat bakteri tersebut berhasil tumbuh sehingga memiliki potensi dalam menurunkan konsentrasi logam berat $\mathrm{Pb}$. Hal ini sesuai dengan peryataan Suyasa (2012) bahwa pada lingkungan atau habitat yang tercemar serta kolam pengolahan limbah dimungkinkan terdapat bakteri pendegradasi zat pencemar, secara alamiah dimana bakteri tersebut dapat bersaing maupun berkonsorsium dengan bakteri lainnya. Bakteri yang diisolasi dari lingkungan yang tercemar logam berat mempunyai tolereansi terhadap logam berat yang ada disekitarnya (Chojnacka, 2010).

Untuk mengetahui kemampuan isolat bakteri indigen dalam menurunkan konsentrasi logam $\mathrm{Pb}$ dilakukan uji reduksi. Hasil uji ANAVA dua arah (Tabel 2) menunjukkan bahwa variasi isolat bakteri, lama perlakuan dan kombinasi keduannya memiliki pengaruh terhadap penurunan (reduksi) logam $\mathrm{Pb} \mathrm{Hal}$ ini ditunjukkan dengan nilai signifikansi kurang dari $\alpha=5 \%$ 
Tabel 2. Hasil Pengujian ANAVA Dua arah

\begin{tabular}{ccc} 
Sumber & Signifikansi & Keterangan \\
Variasi Bakteri & 0.000 & Berbeda Nyata \\
Lama Perlakuan (Hari) & 0.000 & Berbeda Nyata \\
Variasi Bakteri * Hari & 0.000 & Berbeda Nyata \\
\hline
\end{tabular}

Untuk mengetahui pada variasi bakteri mana, hari ke berapa serta kombinasi antara hari dan variasi bakteri yang menyebabkan perbedaan penuruan konsentrasi $\mathrm{Pb}$ maka dilakukan uji lanjutan (Tabel 3).

Tabel 3. Hasil Uji Lanjut Penurunan (Reduksi) Konsentrasi Pb Berdasarkan Variasi Bakteri

\begin{tabular}{ccc}
\hline Variasi Bakteri & $\begin{array}{c}\text { Rata-Rata } \\
\text { (ppm) }\end{array}$ & Notasi \\
\hline A & 1,2131 & $\mathrm{~g}$ \\
$\mathrm{~B}$ & 1,1206 & $\mathrm{f}$ \\
$\mathrm{C}$ & 1,0538 & $\mathrm{e}$ \\
$\mathrm{D}$ & 1,0122 & $\mathrm{c}$ \\
$\mathrm{E}$ & 0,9667 & $\mathrm{~b}$ \\
$\mathrm{~F}$ & 1,0105 & $\mathrm{c}$ \\
$\mathrm{G}$ & 1,0238 & $\mathrm{~d}$ \\
$\mathrm{H}$ & 0,9571 & $\mathrm{a}$ \\
Kontrol & 1,5377 & $\mathrm{~h}$ \\
\hline
\end{tabular}

Berdasarkan Tabel 3 dapat diketahui bahwa semua jenis bakteri memiliki perbedaan penuruan konsentrasi $\mathrm{Pb}$ pada limbah cair agar, terkecuali untuk jenis bakteri $\mathrm{F}$ dan $\mathrm{D}$ yang ditunjukkan dengan notasi sama yaitu c. Hasil uji lanjutan penurunan konsentrasi logam $\mathrm{Pb}$ berdasarkan lama perlakuan (hari) dapat dilihat pada Tabel 4.

Tabel 4. Hasil Uji Lanjutan Reduksi Pb Berdasarkan Hari

\begin{tabular}{cccccccccc}
\hline Hari & 1 & 2 & 3 & 4 & 5 & 6 & 7 & 8 & notasi \\
\hline 1 & - & $0.000^{*}$ & $0.000^{*}$ & $0.000^{*}$ & $0.000^{*}$ & $0.000^{*}$ & $0.000^{*}$ & $0.000^{*}$ & $\mathrm{a}$ \\
2 & & - & $0.000^{*}$ & $0.000^{*}$ & $0.000^{*}$ & $0.000^{*}$ & $0.000^{*}$ & $0.000^{*}$ & $\mathrm{~b}$ \\
3 & & & - & $0.000^{*}$ & $0.000^{*}$ & $0.000^{*}$ & $0.000^{*}$ & $0.000^{*}$ & $\mathrm{c}$ \\
4 & & & & - & $0.000^{*}$ & $0.000^{*}$ & $0.000^{*}$ & $0.000^{*}$ & $\mathrm{~d}$ \\
5 & & & & & - & $0.000^{*}$ & $0.000^{*}$ & $0.000^{*}$ & $\mathrm{e}$ \\
6 & & & & & & - & $0.000^{*}$ & $0.000^{*}$ & $\mathrm{f}$ \\
7 & & & & & & & - & $0.000^{*}$ & $\mathrm{~g}$ \\
8 & & & & & & & & - & $\mathrm{h}$ \\
\hline
\end{tabular}

* : berbeda nyata pada taraf $5 \%$

Berdasarkan Tabel 4 dapat diketahui bahwa terjadi penurunan konsentrasi $\mathrm{Pb}$ dari hari ke hari. Hal ini ditunjukkan dari nilai signifikansi masing pasangan hari yang kurang dari $\alpha=5 \%$ serta notasi yang berbeda. Untuk mengetahui lebih jelas kombinasi antara hari dan variasi bakteri yang menyebabkan penuruan konsentrasi $\mathrm{Pb}$ dapat dilihat pada Gambar 1

Berdasarkan Gambar 1 dapat diketahui bahwa pada setiap jenis bakteri yang diamati selama 8 hari mengalami penurunan konsentrasi logam $\mathrm{Pb}$. Penurunan konsetrasi logam berat $\mathrm{Pb}$ pada limbah cair agar dengan konsetrasi paling kecil terjadi pada hari ke-8 dengan jenis bakteri H yaitu sebesar 0.26 ppm. 

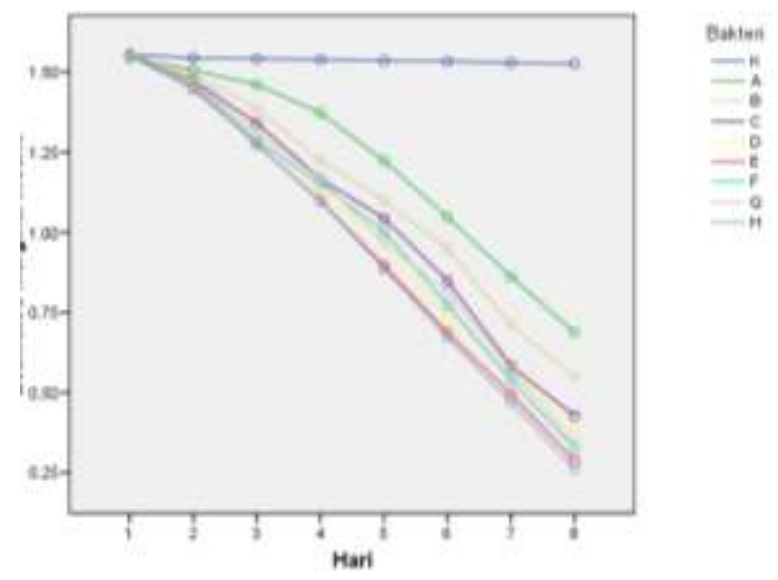

Gambar 1. Grafik Kombinasi Variasi Bakteri dan Hari Terhadap Penurunan Konsentrasi Pb

\begin{tabular}{cccl} 
Tabel 5. Nilai Efisiensi Isolat Bakteri Indigen \\
$\begin{array}{l}\text { Jenis } \\
\text { isolat }\end{array}$ & $\begin{array}{l}\text { Awal } \\
\text { (ppm) }\end{array}$ & $\begin{array}{l}\text { Akhir } \\
\text { (ppm) }\end{array}$ & $\begin{array}{l}\text { Efisiensi } \\
(\%)\end{array}$ \\
\hline A & 1,557 & 0,628 & 59,66 \\
B & 1,557 & 0,552 & 64,54 \\
C & 1,557 & 0,421 & 72,96 \\
D & 1,557 & 0,385 & 72,27 \\
E & 1,557 & 0,291 & 81,31 \\
F & 1,557 & 0,322 & 79,31 \\
G & 1,557 & 0,338 & 78,29 \\
H & 1,557 & 0,255 & 83,62 \\
\hline
\end{tabular}

Berdasarkan hasil uji statistik dan nilai efisiensi tiap isolat bakteri (Tabel 5), maka bakteri indigen limbah cair agar paling potensial dalam mereduksi logam berat $\mathrm{Pb}$ adalah bakteri $\mathrm{F}, \mathrm{E}$ dan $\mathrm{H}$.. Isolat bakteri $\mathrm{F}, \mathrm{E}$ dan $\mathrm{H}$ merupakan isolat bakteri yang memiliki kemampuan menurunkan logam berat $\mathrm{Pb}$ paling potensial, karena ke tiga isolat tersebut dapat menurunkan logam berat $\mathrm{Pb}$ dengan konsentrasi terkecil. Kemampuan efiseiensi reduksi logam berat $\mathrm{Pb}$ isolat $\mathrm{F}$ sebesar 79,31\%, isolat $\mathrm{E}$ sebesar $81,31 \%$ dan isolat $\mathrm{H}$ sebesar $83,62 \%$. Ketiga isolat tersebut mempunyai nilai efisiensi reduksi yang paling tinggi. Nilai akhir konsentrasi logam berat $\mathrm{Pb}$ yang dicapai oleh isolat bakteri $\mathrm{F}$, $\mathrm{E}$ dan $\mathrm{H}$ berturut-turut sebesar 0,32 ppm; 0,29 ppm; dan $0,25 \mathrm{ppm}$. Nilai akhir tersebut telah memenuhi baku mutu air golongan 4

Perbedaan kedelapan isolat bakteri dalam menurunkan logam $\mathrm{Pb}$ dapat disebabkan oleh perbedaan metabolisme dari masing-masing isolat. Metabolisme bakteri berkaitan erat dengan mekanisme toleransi atau resitensi bakteri terhadap logam berat $\mathrm{Pb}$. Sebagian besar bakteri toleran terhadap logam berat dengan cara melakukan mekanisme efflux (Spain, 2003). Terdapat juga mekanisme toleransi atau resistensi lainya, yaitu dengan cara kompleksasi meliputi produksi polisakarida ekstraselular (EPS) bersifat anion yang berfungsi sebagai bioakumulator, produksi metabolit organik yang memiliki sifat pengkelat dan membentuk kompleks dengan logam, presipitasi, kristalisasi ekstraselular oleh bakteri pereduksi sulfat sehingga membentuk deposit sulfida yang kaya akan logam dan biakumulasi interseluler melalui pembentukan metallotionein (protein kaya sistein dalam sel dapat mengikat logam) yang berfungsi untuk detoksifikasi, penyimpanan, dan regulasi ion logam dalam sel (Naik \& Dubey, 2013). 
Ketiga isolat bakteri yang paling berpotensi mereduksi Pb selanjutnya dilakukan karakterisasi dan identifikasi. Ketiga isolat bakteri memiliki karakter yang sama yaitu bakteri Gram Positif dan berbentuk basil (Gambar 2). Hasil identifikasi menggunakan Microbact TM GNB 12A/B/E, 24 Identification Kits disajikan pada Tabel 6.
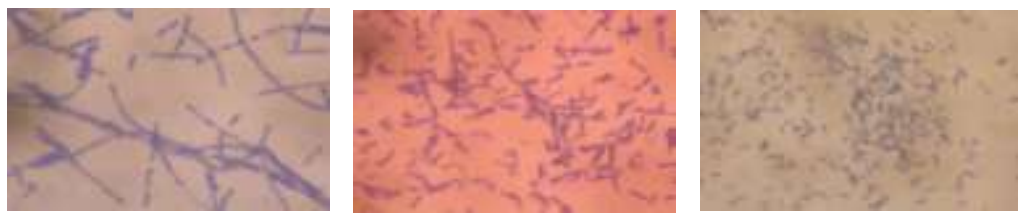

Gambar 2. Pewarnaan Gram Isolat H, E dan F dari kanan ke kiri

Tabel 6. Hasil Uji Microbact TM GNB 12A/B/E, 24 Identification Kits

\begin{tabular}{|c|c|c|c|}
\hline Jenis Tes & E & $\mathrm{F}$ & $\mathrm{H}$ \\
\hline BGP & + & + & + \\
\hline Spora & + & + & + \\
\hline \multicolumn{4}{|l|}{ FERMENT GULA-GULA } \\
\hline Glukosa & + & + & + \\
\hline Xylosa & - & + & - \\
\hline Mannitol & + & + & - \\
\hline Laktosa & - & - & - \\
\hline Sukrosa & + & + & + \\
\hline Maltosa & + & + & + \\
\hline Arabinosa & + & + & - \\
\hline \multicolumn{4}{|l|}{ SUHU PERTUMBUHAN } \\
\hline $20^{\circ} \mathrm{C}$ & + & + & + \\
\hline $37^{\circ} \mathrm{C}$ & + & + & + \\
\hline $40^{\circ} \mathrm{C}$ & + & + & + \\
\hline $45^{\circ} \mathrm{C}$ & + & + & + \\
\hline \multicolumn{4}{|l|}{ TUMBUH DI } \\
\hline Nutrient Broth & + & + & + \\
\hline SDA & - & - & - \\
\hline TSI & $\mathrm{A} / \mathrm{AH} 2 \mathrm{~S}-$ & $\mathrm{A} / \mathrm{AH} 2 \mathrm{~S}-$ & $\mathrm{A} / \mathrm{AH} 2 \mathrm{~S}-$ \\
\hline Citrat & + & + & - \\
\hline Indol & + & - & + \\
\hline VP & + & + & + \\
\hline Indol & + & - & + \\
\hline VP & + & + & + \\
\hline $\mathrm{NaCl} 7 \%$ & + & - & + \\
\hline Mortilitas & + & + & + \\
\hline Strach Hidrolisis & - & + & + \\
\hline Casein Hidrolisis & + & + & + \\
\hline PENICILIN & Sensitif & Sensitif & Sensitif \\
\hline BETA-HEMOUSA & + & + & + \\
\hline Katalase & + & + & + \\
\hline Oksidase & + & + & + \\
\hline Reduksi Nitrat & - & + & - \\
\hline $\begin{array}{c}\text { Reduksi Metylene Blue } \\
\text { DX-Lab }\end{array}$ & - & $\stackrel{-}{\text { R lichonformic }}$ & - \\
\hline$D X-L a b$ & B. pumilus & B. lichenformis & B. alvei \\
\hline
\end{tabular}

Tabel 6 menunjukkan bahwa ketiga isolat bakteri indigen tersebut dalam genus yang sama yaitu genus Bacillus. Bakteri yang tergolong genus Bacillus merupakan bakteri yang resisten terhadap logam berat $\mathrm{Cu}, \mathrm{Cd}, \mathrm{Pb}$ dan $\mathrm{Hg}$ (Zulaika, dkk., 2012). Bakteri Bacillus merupakan bakteri lokal yang mampu menyerap logam berat kedalam sel-selnya sehingga logam berat tersebut tidak dapat bergerak kedalam substrat lebih jauh atau terbawa aliran air bawah (Pudji dkk., 2006). Hasil 
identifikasi menunjukkan bahwa Isolat $\mathrm{H}$ merupakan spesies Bacillus alvei, isolat $\mathrm{E}$ merupakan spesies Bacillus pumilus dan isolat $\mathrm{F}$ merupakan spesies Bacillus lichenformis.

\section{SIMPULAN}

Isolat bakteri indigen limbah cair agar yang berpotensi untuk mereduksi logam $\mathrm{Pb}$ adalah isolat $\mathrm{H}, \mathrm{E}$ dan $\mathrm{F}$. Ketiga isolat mampu menurunkan logam $\mathrm{Pb}$ pada limbah cair agar steril sebesar 83,62\%, 81,31\% dan 79,31\%. isolat Bakteri $\mathrm{H}$ merupakan Bacillus alvei, isolat E merupakan spesies Bacillus pumilus dan isolat $\mathrm{F}$ merupakan spesies Bacillus lichenformis

\section{REFERENSI}

Chojnacka, K. (2010). Biosorption and Bioaccumulation The Prospects for Practical Applications. Environment International, 39 (3): 299-307.

Fidiastuti, H., \& Suarsini, E. (2017). Potensi Bakteri Indigen dalam Mendegradasi Limbah Cair Pabrik Kulit Secara In Vitro. Bioeksperimen: Jurnal Penelitian Biologi, 3(1), 1-10.

Gerdhart, K.E., Huang, X., Bernard R., Greenberg., and Bruce, M. (2008). Phytoremediation of organic soil contaminants: Potential and Challenges. Plant Science, 176 (1):20-30.

Gusnita, D. (2012). Pencemaran Logam Berat Timbal Di Udara dan Upaya Penghapusan Bensin Bertimbal. Berita Dirgantara, 13 (3): 95-101.

Gupta, V.K dan Rastolgi, A. (2008). Biosorption of Lead (II) From Aques Solutions by Non Living Algal Biomass Oedogonium sp. and Nostoc sp.: A Comparative Study, Colloids and Surfaces. Colloids and Surfaces B: Biointerfaces, 64 (2): 170-178.

Khasanah, Eliya. (2009). Adsorpsi Logam Berat. Oseana, XXXIV(4), 1-7.

Lutfi, SR., Wignyanto, \& Kurniati, E. (2018). Bioremediasi Merkuri Menggunakan Bakteri Indigenus dari Limbah Penambangan Emas di Tumpang Pitu Banyuwangi. Jurnal Teknologi Pertanian, 19 (1): 15-24.

Naik, M.M, \& Dubey, S.K. (2013). Lead Resistant Bacteria: Lead resistance mechanisms, their application in lead bioremediation and biomonitoring. Ecotoxicology and Environmental Safety, 98(1), 1-7.

Pambudiono, A., Suarsini, E., \& Amin, M. (2017) The Potensial of Indigenous Bacteria for Removing Cadmium from Industrial Wastewater in Lawang East Java. The Jurnal of Tropical Life Science, 8(1), 62-67.

Park, J., Bolan, N., Megharaj, M \& Naidu, R. (2010). Isolation of Phosphate-Solubilizing Bacteria and Characterization of Their Effect on Lead Immobilization. Pedologist, 53(3): 67-75

Peraturan Pemerintah Republik Indonesia Nomor 82 Tahun 2001. Tentang Pengelolaan Kualitas Air dan Pengendalian Pencemaran Air.

Pudji S.R, Sumingkrat, Noer. S.T, Agustina S, Trisni A, Rofienda, \& Deni. (2006). Penelitian Bioremediasi (Ex-Situ) Tanah Terkontaminasi Limbah B3 Yang Mengandung Logam Berat. Buletin Penelitian, 28 (1): 8-17.

Suhendrayatna. (2001). Bioremoval Logam Berat dengan Menggunakan Microorganime: Suatu Kajian Kepustakaan (Heavy metal bioremoval by microorganisms: A literature study). Prosiding Bioteknologi untuk Indonesia Abad 21. Sinergy Forum - PPI Tokyo Institute of Technology 
Suyasa, I.WB. (2012). Bakteri Pendegradasi Minyak Dari Beberapa Sedimen Perairan Tercemar dan Bak Penampungan Limbah. Bumi Lestari Journal of Environment, 7(1): 1-6.

Spain, A. (2003). Implications of microbial heavy metal tolerance in the environment. Reviews in Undergraduate Research 2, 1-6.

Vijayaraghavan, K. \& Yun, Y.S. (2008). Bacterial biosorbents and biosorption. Biotechnology Advances., 26 (3): 266-291.

Zahoor, A. \& Rehman, A. (2009). Isolation of $\mathrm{Cr}(\mathrm{VI})$ reducing bacteria from industrial effluents and their potential use in bioremediation of chromium containing wastewater. Journal of Environmental Sciences , 21 (6): $814-820$

Zulaika, E. (2012). Bakteri Resisten Logam Berat Yang Berpotensi Sebagai Biosorben dan Bioakumulator. Seminar Nasional Waste Managament For Suistainable Urban Developing Teknik Lingkungan ITS. Surabaya: ITS 